\section{Invalidity and Retrospectivity under the Irish and Canadian Constitutions}

\section{Ailbhe O’Neill}

\section{Introduction}

The question of the temporal effect of a finding that a statute is unconstitutional has arisen in a number of common law jurisdictions. In any legal system that allows its superior courts to strike down legislation, certain practical problems will inevitably emerge. This article explains this aspect of Irish constitutional interpretation and compares the manner in which these difficulties have been addressed under the Canadian and Irish constitutions. It notes that the Supreme Court of Canada was required to address these practical problems directly at an early stage and thus developed a more doctrinally coherent approach to findings of constitutional invalidity than the Irish Supreme Court. The article goes on to analyze a recent decision of the Irish Supreme Court that has highlighted the difficulties with the approach adopted in that legal system and concludes with some reflections on the relative merits of the Canadian approach to findings of invalidity.

\section{The Canadian and Irish Constitutional Provisions}

The Canadian and Irish constitutions have broadly similar provisions requiring laws to be compatible with the provisions thereof. In Canada, the Constitution Act, 1982 provides that:
The Constitution of Canada is the supreme law of Canada, and any law that is inconsistent with the provisions of the Constitution is, to the extent of the inconsistency, of no force or effect. ${ }^{1}$

The provision upon which judges rely in the context of pre-1937 statutes in Ireland is article 50.1 of the 1937 Irish Constitution, which provides as follows:

\section{Subject to this Constitution and to the extent to which they are not inconsistent therewith, the laws in force in Saorstát Éireann [Irish Free State] immediately prior to the date of the coming into operation of this Constitution shall continue to be of full force and effect until the same or any of them shall have been repealed or amended by enactment of the Oireachtas [National Parliament]. ${ }^{2}$}

While the provisions of both constitutions are similar, they have been interpreted quite differently as far as the effect of a finding of unconstitutionality is concerned. The Supreme Court of Canada decided early on that it had the jurisdiction to suspend the effect of a finding of unconstitutionality. The Irish Supreme Court adopted a more absolutist approach to this issue, adopting and adhering to the "void $a b$ initio doctrine." The next section explores some of the early Irish cases in which this approach was taken. It will be seen that it was clear from the outset that certain potentially chaotic consequences could arise from this approach. 


\section{Irish Cases on Invalidity: The "Void $a b$ initio Doctrine"}

The superior courts in Ireland ${ }^{3}$ have taken the view that the meaning of article 50.1 is that any law found by a court to be inconsistent with the 1937 Constitution is deemed to be void from the enactment of the Constitution. This doctrine - the "void ab initio doctrine" - creates some obvious practical problems. In particular, it raises a question mark over the validity of acts carried out in reliance on a statute that is later declared to be unconstitutional.

This problem was identified by the dissenting judge in the 1972 case of McMahon v. Attorney General. ${ }^{4}$ In that case, a majority of the Irish Supreme Court found that the legislation governing ballot papers - which had been used in Dáil elections since 1923 - was unconstitutional. ${ }^{5}$ Justice Fitzgerald, in dissent, pointed out that the finding of the majority "raises or could raise the issue as to whether all elections and by-elections since 1923 were unconstitutional." "No litigant sought to pursue this issue, and the Irish Supreme Court has never had to rule on it.

The question again arose in the 1976 case of de Burca v. Attorney General. ${ }^{7}$ Here, parts of the Juries Act, 1927, ${ }^{8}$ which excluded from jury service persons other than ratepayers who held land above a minimum rateable valuation and exempted all women other than those who made a specific application to be considered for jury service, were found to be unconstitutional. Striking down these provisions of the Act, Chief Justice O'Higgins noted in passing that the possible impact of the decision on the thousands of criminal trials that had taken place in front of juries selected under the Act, had caused him "some concern." $\mathrm{He}$ went on to make the obiter comment that any argument that criminal trials concluded in front of juries selected under the Act would be invalidated by " $t$ the overriding considerations of an ordered society." 10

The judgment in de Burca was followed by a case involving a litigant trying to rely on the invalidity of the legislation. In that case, The
State (Byrne) v. Frawley, ${ }^{11}$ the applicant had been tried and convicted by a jury selected in accordance with the Juries Act, 1927 in December 1975. The Supreme Court had handed down its judgment in de Burca during the course of his trial, but the applicant had not raised the issue at that stage. The trial resulted in his conviction and he took an appeal to the Court of Criminal Appeal. Again, he failed to raise any issue in respect of the jury. It was only after this appeal failed that he instituted habeas corpus proceedings under article $40.4 .2^{\circ}$ of the 1937 Constitution on the grounds that his detention was not in accordance with law. The Supreme Court refused him relief on the basis of "preclusion or estoppel," or the lack of permission to relitigate an issue. The Court went on to point out that it was unnecessary to determine the position of a convicted person not in similar circumstances to Frawley who might have raised the issue after conviction.

Justice Henchy delivered the majority judgment in Frawley. He pointed out that two years had passed since de Burca, and concluded:

Such retrospective acquiescence in the mode of trial and in the conviction and its legal consequences would appear to raise an insuperable barrier against a successful challenge at this stage to the validity of such a conviction or sentence. ${ }^{12}$

In these early cases, the Supreme Court was thus able to avoid the potentially chaotic sequelae of its interpretation of article 50.1. A number of members of the bench, however, adverted to the difficulty the Court was storing up by adopting the void $a b$ initio doctrine. In a later case, Murphy v. Attorney General, ${ }^{13}$ a minority of the Irish Supreme Court voiced their concerns about the void ab initio doctrine, preferring a doctrine of prospective rather than retrospective invalidity. ${ }^{14}$

As will be seen in the next section, the Court in Murphy placed some temporal limitations on the remedies available to litigants in the wake of a finding of invalidity. 


\section{Murphy: The Temporal Imitation of Redress}

The Murphy case gave rise to the striking down of certain taxation legislation, a decision with potentially wide-ranging disruptive results. Rather than suspend the effect of the ruling, the Supreme Court chose to focus on the issue of redress. A majority of the Supreme Court endorsed the void $a b$ initio doctrine, but they limited the redress available to the plaintiffs to the recovery of tax paid since the commencement of the constitutional action. The Court also indicated that only those third parties who had raised the issue of the constitutionality of the legislation before the statute was struck down could recover. Justice Henchy stated that while the general rule must be to allow corrective legal proceedings, ${ }^{15}$ "the law has to recognize that there may be transcendent considerations which make such a course undesirable, impractical, or impossible."16

The minority, as noted above, stated a preference of abandoning the void $a b$ initio doctrine in favour of a prospective ruling of invalidity. As can be seen from the next section, this is very close to the approach developed by the Supreme Court of Canada in its jurisprudence.

\section{The Canadian Approach and “Temporary Validity"}

Unlike the Irish Supreme Court, the Supreme Court of Canada was forced to consider the practical problems with findings of invalidity in an early constitutional case that raised the issue quite starkly. In the well-known case of Reference re Manitoba Language Rights, ${ }^{17}$ the Supreme Court of Canada found that all statutes and regulations of the Province of Manitoba that were not printed and published in both English and French were constitutionally invalid. Recognizing the catastrophic results that the immediate striking down of these laws would have, the Court made a novel ruling that gave "deemed temporary validity" to all of the laws affected by the decision. The Court justified this action on the basis of the need to preserve the rule of law. ${ }^{18}$
Similar cases involving the statute books of Saskatchewan ${ }^{19}$ and Alberta ${ }^{20}$ followed, and the Court again used this mechanism to prevent the creation of a legal vacuum in those provinces. ${ }^{21}$

The Court used the "deemed temporal validity" approach in a number of subsequent cases concerning violations of Charter ${ }^{22}$ rights. Most of these cases arose in the context of the criminal justice system. In R. v. Brydges, ${ }^{23}$ the Court provided for a thirty-day transitional period during which police cautions that breached Charter rights could continue to be given. ${ }^{24}$ In $R$. v. Bain,${ }^{25}$ the majority struck down provisions of the Criminal Code ${ }^{26}$ that allowed the Crown but not the accused to "stand by" prospective jurors on the basis that it was contrary to section 11(d) of the Charter. ${ }^{27}$ In this case, the Court allowed for a six-month period of validity to provide an opportunity for Parliament to remedy the situation if it considered it appropriate to do so. ${ }^{28}$ In $R$. $v$. Swain ${ }^{29}$ the Supreme Court struck down certain provisions of the Criminal Code that required a person acquitted on the grounds of insanity to be detained in a psychiatric institution. These provisions were found to violate sections 7 and 9 of the Charter. ${ }^{30}$ The Court held that there should be a six-month "period of temporary validity" to prevent the release of all such detainees. ${ }^{31}$

Apart from the cases concerning the criminal justice system, the Canadian courts also faced the issue in the context of the electoral system. In 1989, in Dixon v. British Columbia (Attorney General), ${ }^{32}$ Supreme Court of British Columbia Chief Justice McLachlin found that provincial legislation prescribing electoral districts for the province of British Columbia was unconstitutional. The statute violated section 3 of the Charter because of the disparity of the voting populations of various districts. She noted that nullification of the legislation would leave the province without any means of holding elections, and took the view that in any system of responsible government it was possible for elections to be held at any time. Chief Justice McLachlin also compared the emergency in the case at hand to the situation in the Manitoba case and held that the unconstitutional laws 
would "stay provisionally in place to avoid the constitutional crisis which would occur should a precipitate election be required." ${ }^{33}$

The legislation was to remain in place for as long as "may reasonably be required to remedy" it with the actual time limit to be fixed by a subsequent court order. ${ }^{34}$ In later proceedings, ${ }^{35}$ such an order was sought but rejected on the basis that the legislature ought to be left "to do what is right in its own time." 36

\section{Consolidating the Canadian Position: Schachter v. Canada}

In Schachter v. Canada, ${ }^{37}$ the Supreme Court of Canada found that a provision of the federal Unemployment Insurance Act ${ }^{38}$ violated the guarantee of equality in section 15(1) of the Charter by giving more generous child care benefits to adoptive than to natural parents. ${ }^{39}$ Chief Justice Lamer pointed out that striking down the statute would simply deprive everyone of the benefits, and found that " $t$ the logical remedy is to strike down but suspend the declaration of invalidity to allow the government to determine whether to cancel or extend the benefits." ${ }^{\prime 4}$

Chief Justice Lamer emphasized that such an order should only be resorted to where less extreme solutions such as severance or reading down were found to be inappropriate. ${ }^{41} \mathrm{He}$ also explored some of reasons why "deemed temporal validity" ought to be a remedy of last resort. He pointed out that such a ruling maintains in force an unconstitutional statute and that it involves a "serious interference" with the legislative process because it "forces the matter back onto the legislative agenda at a time not of the choosing of the legislature, and within time limits under which the legislature would not normally be forced to act." ${ }^{\prime 2}$

The decision in Schachter revisited the earlier Canadian case law on this issue and set a number of limitations on the circumstances in which rulings of temporary validity would be made. Such rulings were only to be made where the striking down of a law with immediate effect would pose a danger to public, threaten the rule of law, or result in the deprivation of benefits from deserving persons.

The Schachter decision was cited by the Irish Supreme Court in its most recent decision on the effect of finding legislation unconstitutional, but the judges, with one (qualified) exception, ${ }^{43}$ rejected the Canadian approach and endorsed once again the void $a b$ initio doctrine. This decision is set out in more detail in the next section.

\section{Introduction to the $A$. Case: The Irish Courts Revisit the Issue of Invalidity}

The Irish Supreme Court recently revisited the question of the effect of a finding of unconstitutionality in A. v. The Governor of Arbour Hill Prison. ${ }^{44}$ This case arose out of a habeas corpus application by a man who had pleaded guilty to an offence of unlawful carnal knowledge of a girl under fifteen contrary to section 1(1) of the Criminal Law Amendment Act, $1935,{ }^{45}$ and who received a three-year custodial sentence. An unrelated individual, C.C., charged with the same offence, challenged the constitutionality of section 1(1) in a case taken approximately eighteen months after Mr. A began serving his sentence. In its judgment in the C.C. case,${ }^{46}$ the Irish Supreme Court declared the offence to which Mr. A had pleaded guilty to be inconsistent with the 1937 Constitution on the basis that it precluded a defence of honest and reasonable mistake. The Court made a declaration to that effect under article 50.1 of the 1937 Constitution, effectively striking down section 1(1) of the Criminal Law Amendment Act, 1935.

After the judgment in C.C. was handed down, Mr. A made an application to the High Court under Article 40.4.2 ${ }^{\circ}$ of the 1937 Constitution, seeking his release from custody on the grounds that there was no lawful basis for his detention. ${ }^{47}$ His argument was that the application of this approach to findings of invalidity meant that the offence for which he was convicted had never actually existed. 
In the High Court, ${ }^{48}$ Justice Laffoy delivered a short judgment ordering the immediate release of the respondent from custody. The judgment relied heavily on the void ab initio doctrine, and noted that the offence "ceased to have legislative existence in 1937" when the 1937 Constitution came into force. ${ }^{49}$

\section{Retrospectivity and Continuing Detention}

One of the curious aspects of the $A$. case is the fact that so much emphasis was placed on the troubled question of the effect of a finding of invalidity on the conviction and sentencing of the applicant at the time these occurred. This focus on the question of "retrospectivity," as it was framed by the Court, was arguably misguided. Article $40.4 .2^{\circ}$ of the 1937 Constitution requires the state to justify the continuing detention of a habeas corpus applicant. The resolution of this issue does not necessitate finding that the original conviction and sentence were constitutionally frail, only that their continuation in force cannot be justified so as to allow for an existing and future deprivation of liberty. Despite this, the Supreme Court unanimously assumed that a finding in favour of the applicant would involve some element of retrospectivity and approached the case on that basis.

\section{The Judgments in the Supreme Court}

One of the key aspects of the judgments in the $A$. case was the parsing of the question "what is the effect of striking down a statute?" into two issues: (1) the time from which the statute is ineffective, and (2) the issue of redress. This approach had also been taken in Murphy. ${ }^{50}$ Whatever the validity of the approach in that case - and it is arguably inconsistent with a strict void $a b$ initio approach - the situation in the two cases as regards redress were not comparable. In Murphy, the approach operated so as to prevent litigants claiming restitution of invalidly paid tax. The applicant in the $A$. case was in a different position - he was not claiming damages for unlawful detention in the past (which would be analogous to Murphy). Rather, he was claiming that the state could not justify continuing to deprive him of his liberty after that deprivation had been found to be constitutionally infirm. Despite the findings of the High Court on this point, each member of the Supreme Court adopted this two-step test in $A$.

There was, however, some variation in the way that each Supreme Court judge explored the second issue. The Chief Justice took the view that the doctrine of res judicata precluded the reopening of the applicant's conviction. This is a novel approach to Irish constitutional interpretation, as the doctrine of res judicata is a common law doctrine that had never before been relied upon in the context of constitutional precedent, and no justification is offered in the judgment for this sudden transplantation.

The Irish courts, as with many of their common law counterparts, tend to rely on a variety of interpretive tools ${ }^{51}$ when analyzing the 1937 Constitution. ${ }^{52}$ One of the prevalent approachesin recentconstitutionaljurisprudence is the "harmonious approach." ${ }^{53}$ In $A$., Chief Justice Murray relied on this interpretive method in his judgment, where he emphasized the importance of interpreting article 50.1 in light of the constitution as a whole. He referred in his judgment to the competing constitutional considerations. Interestingly, Chief Justice Murray identified these considerations as being comprised of the rights of the applicant and the interests of justice, including the rights of the victim. What is striking about this interpretation is that there is little emphasis placed on the constitutional right to liberty, which is one of the fundamental rights in the Irish constitutional order. ${ }^{54}$ Justice Hardiman, who also took a harmonious approach, also avoided reference to this competing value. In his judgment, he made reference to the Preamble of the 1937 Constitution, which refers to the promotion of the "common good" and the attainment of "true social order." The same paragraph of the Preamble also refers to the 
assurance of "the dignity and freedom of the individual," but again no emphasis is placed on this value.

Apart from this interpretive tool, Chief Justice Murray and Justice Hardiman also made reference to "transcendent considerations" 55 that rendered complete or absolute retrospectivity inappropriate. The source and content of these "transcendent considerations" was not articulated, but the phrase was used by the Chief Justice to refer to public policy considerations and the fact that "many things of great public or private significance may have taken place by virtue of an impugned measure." ${ }^{56}$ Justice Hardiman's judgment took a similar approach in this regard. Both judges referred to earlier case law such as McMahon, ${ }^{57}$ in support of the limitations of retrospectivity. In fact, the question of redress did not arise for judgment in those cases so that any conclusions drawn in the judgments in that regard were obiter.

\section{A Comparative Excursus}

The Chief Justice was the only member of the Court to engage in an extensive comparative survey of other legal systems, referring to the jurisprudence of the European Court of Human Rights, ${ }^{58}$ the Supreme Court of India, ${ }^{59}$ the United States Supreme Court, ${ }^{60}$ and the Supreme Court of Canada ${ }^{61}$ in passing. As far as the latter jurisdiction was concerned, the Schachter case $^{62}$ was not referred to in his judgment, but reference was made to Bain.

In fact, the jurisdiction on which the most analysis focused was the European Court of Justice (ECJ) rulings on the interpretation of the European Community Treaties. ${ }^{63}$ Chief Justice Murray's comparative survey started with the European Union. ${ }^{64} \mathrm{He}$ noted that the jurisprudence on requests for preliminary ruling under article 235 of the EC Treaty reveal that the ECJ sometimes limits the retroactive effect of its ruling and sometimes allows those who have brought proceedings prior to the ruling to maintain them. Article 231 of the EC Treaty provides that the ECJ, in declaring a measure void, may state which of the effects of the regulation that it found void are to be definitive. The Chief Justice referred to the ECJ's practice (similar to that of the Supreme Court of Canada) of maintaining the impugned provision in effect until a new valid measure was adopted. ${ }^{65}$

Finally, Justice Denham also made some reference to the Canadian case $\operatorname{law}^{66}$ and the jurisdiction of the Supreme Court of Canada to suspend findings of invalidity, but ultimately did not approve of the adoption of that approach in Ireland.

\section{Reflections on the Canadian and Irish Approaches}

The approach taken by the Irish Supreme Court in the $A$. case can be criticized for its arguable lack of consistency with earlier case law and its overreliance on obiter dicta from such case law. It can also be criticized for insisting on the continued adoption of the void $a b$ initio doctrine while compounding the incoherence in the doctrine arguably first exposed in Murphy. While it has been argued here that the $A$. case did not require the Court to adopt a position on retrospectivity and limitation of relief, the Court nonetheless ruled on these issues and some reflections on the alternative Canadian approach merit discussion.

The Canadian approach is not uncontroversial, and has even been described as "radical," 67 but one of the advantages of the Canadian approach is that it has a consistency to it that is arguably lacking in the Irish jurisprudence. The consolidation of the case law in the Schachter ${ }^{68}$ decision refined the situations in which the Court would exercise this tool of "deemed temporal validity," and confined it to discrete categories of cases.

Indeed, some of the Irish case law on invalidity pre- $A$. involved situations that could usefully havebeen dealt with under the Canadian approach post-Schachter by the suspension of a finding of invalidity. For example, electoral cases such as McMahon ${ }^{69}$ would clearly fall under the rule of law category. On the other hand, 
the Schachter criteria are themselves malleable and their precise extent can vary from case to case. Thus, what constitutes a "threat to the public" may not always be clear. Depending on the breadth of meaning given to that concept, the application of Schachter in C.C. ${ }^{70}$ might not necessarily have put $\mathrm{Mr}$. A in any better a position.

One of the criticisms that can be made of the Canadian approach is that it involves the Court in a counterintuitive and unpalatable exercise of positively retaining in force an unconstitutional law. However, the approach does have the advantage of requiring the Court to articulate the reasons justifying that decision in a categorical way, and avoids vague language such as "transcendent considerations." For its transparency alone, the Canadian approach is perhaps to be preferred in any constitutional order where an unelected judiciary is the primary guardian of the constitution.

Prior to the $A$. case, it had been suggested in Ireland that "the interesting Canadian case law might prompt the Supreme Court to reassess some of the more rigid and uncompromising aspects of the Murphy decision." ${ }^{71}$ The opportunity to consider the merits of that approach arose in the $A$. case, where Justice Denham's judgment alone offered some specific support for the Schachter approach. She noted that "such a suspended declaration is in aid of organised society as it enables the legislature address the issue" and "enables dialogue in the community as to the best way to proceed." $72 \mathrm{Her}$ approval of the approach was cautious, however, and she went on to note that the Canadian "case law may not be referable or persuasive to our Constitution."73

The reasons why this is so are not made clear, but may be due, in part at least, to the strict view of the "separation of powers" that has been espoused by the current Irish Supreme Court. ${ }^{74}$ Even discounting the dogged adherence of the Court to the void $a b$ initio doctrine, the idea of a doctrine that would involve the Court in a dialogue with the legislature is unlikely to find favour with the current Irish Supreme Court.

\section{Notes}

* Dr. Ailbhe O’Neill, Barrister and Lecturer in Law, Trinity College Dublin, ailbhe.oneill@tcd.ie.

1 Constitution Act, 1982, s. 52(1), being Schedule B to the Canada Act 1982 (U.K.), 1982, c. 11.

2 Constitution of Ireland, art. 50.1, online: Department of the Taoiseach <http://www. taoiseach.gov.ie/attached_files/Pdf\%20files/ Constitution\%20of\%20IrelandNov2004.pdf> [1937 Constitution].

3 There are two superior courts of record in Ireland - the High Court and the Supreme Court.

These are the only courts with jurisdiction in constitutional matters.

4 [1972] I.R. 69, Fitzgerald J. [McMahon].

5 The Court found that the legislation did not provide for the complete secrecy of the ballot as required by art. $16.1 .4^{\circ}$ of the 1937 Constitution, supra note 2.

6 Supra note 4 at 113.

7 [1976] I.R. 38 [de Burca].

8 (Ire.), No. 23/1927.

9 Supra note 7 at 63.

10 Ibid.

11 [1978] I.R. 326 [Frawley].

$12 \mathrm{Ibid}$. at 349.

13 [1982] I.R. 241 [Murphy].

14 See O'Higgins C.J. in the minority in Murphy, ibid. at 301. See also the dissenting judgments in the earlier Supreme Court case of McMahon, supra note 4.

15 See Muckley v. Ireland, [1985] I.R. 472, where the Supreme Court held that the restriction of redress did not apply to taxes that were assessed, but uncollected.

16 Supra note 13 at 314.

17 [1985] 1 S.C.R. 721, 1985 CanLII 33 [Manitoba].

18 See discussion of the decision in Peter W. Hogg, Constitutional Law of Canada, $4^{\text {th }} \mathrm{ed}$. (Scarborough, ON: Carswell, 1997) at 922, where the author states that "'necessity' would have been the more conventional rubric" for the decision.

19 R. v. Mercure, [1988] 1 S.C.R. 234, 1988 CanLII 107.

20 R. v. Paquette, [1990] 2 S.C.R. 1103, 1990 CanLII 37.

21 See also Sinclair v. Quebec (Attorney General), [1992] 1 S.C.R. 579, 1992 CanLII 126, where the Court used the approach to maintain in force bylaws and other acts of a Quebec municipality that had been invalidly incorporated but functioning for six years.

22 Canadian Charter of Rights and Freedoms, Part I of the Constitution Act, 1982, supra note 1 
[Charter].

23 [1990] 1 S.C.R. 190, 1990 CanLII 123.

24 See also R. v. Askov, [1990] 2 S.C.R. 1199, 1990

CanLII 45.

25 [1992] 1 S.C.R. 91, 1992 CanLII 111 [Bain].

26 R.S.C. 1985 , c. C-46.

27 Section 11(d) provides that "[a]ny person charged with an offence has the right to be presumed innocent until proven guilty according to law in a fair and public hearing by an independent and impartial tribunal."

28 Supra note 25 at 165.

29 [1991] 1 S.C.R. 933, 1991 CanLII 104.

30 Section 7 provides that " $[\mathrm{e}]$ veryone has the right to life, liberty and security of the person and the right not to be deprived thereof except in accordance with the principles of fundamental justice." Section 9 provides that "[e]veryone has the right not to be arbitrarily detained or imprisoned."

31 Supra note 29 at 1021 and 1037.

32 (1989), 59 D.L.R. (4 $\left.{ }^{\text {th }}\right)$ 247, 1989 CanLII 248 (B.C.S.C.).

33 Ibid. at 284.

34 Ibid.

35 Dixon v. British Columbia (A.G.) (1989), 60 D.L.R. $\left(4^{\text {th }}\right) 445$ (B.C.S.C.).

36 Ibid. at 448.

37 [1992] 2 S.C.R. 679, 1992 CanLII 74 [Schachter].

38 Currently the Employment Insurance Act, S.C. 1996, c. 23.

39 Section 15(1) of the Charter, supra note 22 provides that "[e]very individual is equal before and under the law and has the right to the equal protection and equal benefit of the law without discrimination and, in particular, without discrimination based on race, national or ethnic origin, colour, religion, sex, age or mental or physical disability."

40 Supra note 37 at 716.

41 In Ireland, "reading down" is the preferred approach to statutes that post-date the 1937 Constitution, supra note 2 , as these enjoy a strong presumption of constitutionality. See East Donegal Co-Operative Livestock Mart Ltd. v. Attorney General, [1970] I.R. 317.

42 Supra note 37 at 716-17.

43 Justice Denham alone advocated prospective overruling. See discussion below.

44 [2006] IESC 45 (BAILII) [A.].

45 (Ire.), No. 6/1935.

46 C.C. v. Ireland, [2006] IESC 33 (BAILII) [C.C.].

47 Article $40.4 .2^{\circ}$ of the 1937 Constitution, supra note 2 , specifically provides for habeas corpus applications to the High Court as follows:
Upon complaint being made by or on behalf of any person to the High Court or any judge thereof alleging that such person is being unlawfully detained, the High Court and any and every judge thereof to whom such complaint is made shall forthwith enquire into the said complaint and may order the person in whose custody such person is detained to produce the body of such person before the High Court on a named day and to certify in writing the grounds of his detention, and High Court shall, upon the body of such person being produced before that Court and after giving the person in whose custody he is detained an opportunity of justifying the detention, order the release of such person from detention unless satisfied that he is being detained in accordance with the law.

48 A. v. The Governor of Arbour Hill Prison, [2006] IEHC 169 (BAILII), Laffoy J.

49 Ibid.

50 Supra note 13.

51 The Irish courts have evolved a number of techniques of interpretation since the Constitution was promulgated in 1937. These include the literal approach, the historical approach, the broad or purposive approach, and the natural law approach. For an excellent summary of the case law relating to Irish constitutional interpretation, see Gerard Hogan \& Gerry Whyte, eds., J.M. Kelly: The Irish Constitution, $4^{\text {th }}$ ed. (Markham, ON: LexisNexis Butterworths, 2003) at 3-38.

52 Supra note 2.

53 Dillane v. Ireland, [1980] I.L.R.M. 167 is the earliest example of the application of this method of interpretation.

54 Personal liberty is protected under Article 40.4.1 ${ }^{\circ}$ of the 1937 Constitution and provides that " $[\mathrm{n}] \mathrm{o}$ citizen shall be deprived of his personal liberty save in accordance with law."

55 The phrase is borrowed from the judgment of Henchy J. in Murphy, supra note 13. See also the judgment of Hardiman J. in A., supra note 44.

56 A., ibid.

57 Supra note 4.

58 Marckx v. Belgium (1979), 2 E.H.R.R. 330, [1979] E.C.H.R. 2 (BAILII).

59 India Orissa Cement Ltd. v. State of Orissa [1991] Supp. (1.) SCC 4330.

60 The U.S. Supreme Court decision of Chicot County Drainage District v. Baxter State Bank, 308 U.S. 371 (1940) (FindLaw) had already been referred to by Henchy J. in Murphy, and Murray C.J. referred to this decision and three later decisions in A.: Linkletter v. Walker, Warden, 381 U.S. 618 (1965) (FindLaw); Tehan, Sheriff v. United States (Ex. Rel. Shott), 382 U.S. 406 (1966) 
(FindLaw); and Stovall v. Denno, Warden, 388 U.S. 293 (1967) (FindLaw).

61 Bain, supra note 25; and R. v. Wigman, [1987] 1 S.C.R. 246, 1987 CanLII 1.

62 Supra note 37.

63 See European Union, Consolidated Version of the Treaty on European Union and of the Treaty Establishing the European Community, [2006] O.J.C 321/1.

64 In Murphy, supra note 13, reference was made to the ECJ's decision in Defrenne v. Sabena, [1976] 2 CMLR 98.

65 C-178/03 Commission v Parliament [2006] ECR 1-0.

66 Bain, supra note 25; Schachter, supra note 37; and Corbiere v. Canada (Minister of Indian and Northern Affairs), [1999] 2 S.C.R. 203, 1999 CanLII 687.

67 See Hogg, supra note 18.

68 Supra note 37.

69 Supra note 4.

70 Supra note 46.

71 Hogan \& Whyte, supra note 51 at 906.

72 Supra note 44.

73 Ibid.

74 See Sinnott v. Minister for Education, [2001] 2 I.R. 545, [2001] IESC 63 (BAILII) for an example of the separation of powers doctrine in its most rigid guise. 